\title{
Physico-Chemical and Antioxidant Characteristics in Fruits of Walnut (Juglans regia L.) Genotypes from Inner Anatolia
}

\author{
Omer BEYHAN ${ }^{1}$, Sadiye GOZLEKCI ${ }^{2}$, \\ Muttalip GUNDOGDU ${ }^{3}$, Sezai ERCISLI ${ }^{4 *}$ \\ ${ }^{1}$ Sakarya University, Pamukova Vocational School, 54900 Pamukova, Sakarya, Turkey; obeyhan@sakarya.edu.tr \\ ${ }^{2}$ Akdeniz University, Agricultural Faculty, Department of Horticulture, 07059 Antalya, Turkey; sgozlekci@gmail.com \\ ${ }^{3}$ Abant Izzet Baysal University, Faculty of Agriculture and Natural Science, 14280 Bolu, Turkey; gundogdu_m@hotmail.com \\ ${ }^{4}$ Ataturk University, Agricultural Faculty, Department of Horticulture, 25240 Erzurum, Turkey; sercisli@gmail.com ("corresponding author)
}

\begin{abstract}
Walnut fruits are used for their nutrition properties for a long time in Anatolia, where seed propagated walnuts are naturally found, as solitary individuals or dense populations. Some relevant physico-chemical and antioxidant characteristics of fruits were determined for fifteen promising walnut (Juglans regia L.) selections (named 'G-1' to 'G-15') propagated from seeds. The well-known Turkish walnut cultivar 'Sebin' was included in the analysis as a standard in order to make comparison with seed propagated genotypes. The average fruit weight and kernel ratios ranged from 7.43 to $12.61 \mathrm{~g}$ and 45.10 to $57.83 \%$ among the studied genotypes, respectively. The chemical analyses showed that protein, crude oil, ash, carbohydrate and dietary fiber contents of the analyzed walnut genotypes were between $11.09-18.16 \%, 55.38-65.15 \%, 1.61-2.08 \%, 12.01-17.89 \%$ and 2.90-4.12\%, respectively. Total phenolic content was found between 1,107-1,876 mg GAE/100 g among the genotypes and most of them had higher phenolic content compared with cv. 'Sebin'. The total tocopherols content ranged from 30.0 to 44.4 $\mathrm{mg} / 100 \mathrm{~g}$ of the extracted oil. The most common tocopherol in all samples was $\gamma$-tocopherol. The results obtained in the hereby study indicated that the seed propagated walnut trees can be very diverse and their nuts have a good potential for valuable sources of phytochemicals.
\end{abstract}

Keywords: walnut, chemical diversity, tocopherols

\section{Introduction}

Juglans regia L. is native to a wide region extending from the Carpathian Mountains across Turkey, Iraq, Iran, Afghanistan and southern Russia, far away to China; are generally grown at commercial scale in USA, European and Asian countries (Ercisli, 2004). Turkey is one of the main walnut producers in the world with annually 183,000 tons of walnut production and ranking 4th place after China (1,655,000 tons), Iran (485,000 tons) and USA (418,000 tons) (FAO, 2012).

Anatolia represents also a germplasm center of walnut and walnut trees are exceptionally abundant within almost all regions in Turkey. Walnut trees are cultivated in Turkey mainly for their nutritious nuts, which are used as a food, in the chocolate industry, for baked foods, as well as in the pharmaceutical and cosmetic industry. The trees are also valuable as timber (Ercisli et al., 2012).
Continuous seed propagation in Turkey has given rise to a great number of seedling walnut trees, which represent valuable walnut gene resources. The number of native trees is estimated to be over 5 million and they possess large genetic variability in yield, nut and kernel characteristics, late bud breaking, late flowering, winter hardiness, tolerance to disease etc. (Sen and Tekintas, 1992). This high genetic variation of native walnut populations throughout the country represent good opportunities for walnut breeding to obtain new cultivars directly or to use them in cross breeding activity (Ercisli, 2004).

Nuts are part of a healthy diet such as the Mediterranean diet. Benefits of nuts in reducing the risk of heart disease has been reasonably attributed to their composition of vitamins, minerals, unsaturated fatty acids, fiber and phytochemicals such as polyphenols, tocopherols, squalene and phytosterols. More than $75 \%$ of total fatty acids of nuts are unsaturated. $\alpha$-tocopherol is the main tocopherol isomer present in most of the nuts. Walnuts, Brazil nut, cashew nut, peanut, pecan 
and pistachio are rich in $\gamma$-tocopherol wheeras $\beta$ - sitosterol is dominant sterol in nuts (Chen and Blumberg, 2008).

Although walnuts are rich in fat, a diet supplemented with walnuts had a beneficial effect on blood lipids, lowering blood cholesterol and lowering the ratio of serum concentrations of low density lipoprotein: high density lipoprotein by 12\% (Sabate et al., 1993; Savage, 2001). Oil contents of walnut kernels can generally vary from 52 to $70 \%$ depending on the cultivar, location grown and irrigation rate (Zvarts et al., 1999; Savage, 2001; Caglarirmak, 2003). Most nuts are rich in monounsaturated fat (oleic acid), while walnuts are also high in two polyunsaturated fatty acids: linoleic acid and $\alpha$ linolenic acids. The major fatty acids found in walnut oil are linoleic, oleic and linolenic acids (Beyhan et al., 1995; Zvarts et al., 1999). The fatty acid profile of walnut oil varies between cultivars. It is important to identify these differences in locally grown genotypes and to identify which fatty acids give the best nutritional qualities (Greve $e t$ al., 1992; Zvarts et al., 1999).

Consumption of walnuts and its oil, due to presence of high concentration of natural antioxidants, has been reported as being protective against certain types of cancer and may also decrease the risk of cardiovascular diseases (Miraliakbari and Shahidi, 2008; Yang et al. 2009).

Previously only few studies, based on a very limited number of seed propagated genotypes, have been reported on the physico-chemical and antioxidant characteristics of walnut fruits (Greve et al., 1992; Zvarts et al., 1999). Thus, more data are needed about the biodiversity of this fruit in order to identify the most nutritious genotypes based on the fruits' content and thus to enhance their commercial value. The current study was undertaken to bring new information on some physicochemical characteristics and antioxidant capacity of fifteen walnut genotypes from Turkey.

\section{Materials and Methods}

\section{Plantmaterial}

Fifteen walnut genotypes ('G-1' to 'G-15') and one commercial cultivar ('Sebin') were analyzed. The walnut fruits of the studied genotypes were collected from Gumushane province located in northeastern Turkey. The walnut fruits were harvested in September during the 2014 crop year. After the harvest, the walnut fruits were immediately dried and stored in the shell at room temperature until the beginning of the analysis. The nut traits were measured using 20 nuts chosen randomly.

\section{Determination of physico-chemical characteristics}

For fruit weight, each fruit was measured with an electronic balance of $0.01 \mathrm{~g}$ sensitivity. Kernel ratio was determined by using kernel weight/fruit weight. Ash analysis was carried out by heating the sample in a muffle furnace at $525^{\circ} \mathrm{C}$ for $8 \mathrm{~h}$. The quantity of total protein was calculated by multiplying the nitrogen content, determined using the Kjeldahl method, by the coefficient 6.25 (AOAC, 1990). The carbohydrate content was estimated by calculating the differences based on the other components and using the following formula: Carbohydrate content $(\%)=100 \%$ - (moisture $(\%)+$ protein $(\%)+$ oil $(\%)+$ ash (\%)) (Grosso et al., 2000). The total dietary fiber content was determined by the method applied by Savage (2001). To determine the oil content, the walnuts were grounded in a mill for 30 seconds. Immediately after grinding, the walnuts were extracted for $6 \mathrm{~h}$ with hexane using a Soxhlet apparatus (Paquat and Houtfenne, 1987). The protein, carbohydrate and total oil content of fruits were calculated on a dry weight basis and expressed as $\mathrm{g} / 100 \mathrm{~g}$.

\section{Fatty acid composition}

Fatty acid was measured according to the method described by Savage et al. (1999). In order to evaluate fatty acid composition of walnut oil, a $30 \mathrm{~m} \times 0.22 \mathrm{~mm}, 0.25 \mu \mathrm{m}$ film thickness fused-silica capillary column DB-23 was connected to a Varian 3400 gas chromatograph (Palo Alto, CA) equipped with a flame ionization detector (FID) and split/splitless injector. Helium was used as the carrier gas at a velocity of $23 \mathrm{~cm} / \mathrm{s}$ and as the make-up gas at a rate of $30 \mathrm{~mL} / \mathrm{min}$. A temperature program of $158^{\circ} \mathrm{C}$ for $5 \mathrm{~min}$ rising to $220^{\circ} \mathrm{C}$ at a rate of $5^{\circ} \mathrm{C} / \mathrm{min}$ was used. The fatty acid methyl ester (FAME) dissolved in hexane was injected $(1 \mu \mathrm{L})$ in a split mode of injection at a split ratio of 40:1. The injector and detector temperatures were $230^{\circ} \mathrm{C}$ and $250{ }^{\circ} \mathrm{C}$, respectively. A Varian 4270 integrator was used for recording the peak areas. No response factors were applied in calculating fatty acid composition, since the expand GC temperature program showed almost equal responses for different FAME standard mixtures.

\section{Tocopherols}

The tocopherol composition of oils was analyzed as previously described by Maguire et al. (2004), with minor modifications. Briefly, in screw top tubes fitted with Teflon lined screw top, $40 \mathrm{mg}$ oil with $300 \mathrm{~mL}$ of $50 \% \mathrm{KOH}(\mathrm{w} / \mathrm{v})$ and $2 \mathrm{~mL}$ of $1 \%$ ethanolic pyrogallol $(\mathrm{w} / \mathrm{v})$ was carefully mixed. The test tubes were kept in a thermostated water bath for $42.16 \mathrm{~h}$ at 70 ${ }^{\circ} \mathrm{C}$. After cooling the tubes, $1 \mathrm{~mL}$ of aerated distilled water and 4 $\mathrm{mL}$ hexane were slowly added into. The tubes were agitated under high shaking rate and then centrifuged at 2,000 rpm for 12 $\min$. The hexane layer was removed and the extraction process iterated with a further $2 \mathrm{~mL}$ hexane. The combined hexane extracts were dried under nitrogen gas. The extract was redissolved in $200 \mathrm{~mL}$ ethanol, transferred to a plastic insert in a high-performance liquid chromatography (HPLC) vial and stored at $-20^{\circ} \mathrm{C}$ for later analysis through HPLC.

HPLC system including a $\mathrm{k}$ - 1001 HPLC pump, a k-1001 solvent organizer, an on-line degasser, a dynamic mixing chamber and a scanning HPLC fluorescence detector with the excitation and emission wavelength set at $290 \mathrm{~nm}$ and $330 \mathrm{~nm}$, respectively were used for the analysis of tocopherols in walnut oil samples as previously explained by Pocklington and Dieffenbacher (1988). The separation was performed on a Lichrospher 100 RP-18 silica column $(5 \mathrm{~mm}, 250 \times 4 \mathrm{~mm})$. The isocratic mobile phase used was hexane/2 - propanol $(99.5: 0.05, \mathrm{v} / \mathrm{v})$ at a flow rate of 2 $\mathrm{mL} / \mathrm{min}$. The chromatographic data were collected and recorded using Euro Chrom 2000 software from Knauer, which was controlled by Windows XP. Tocopherol peaks were identified and quantified with the help of an in-house reference solution of $\alpha$-tocopherol, $\beta$-tocopherol, $\gamma$-tocopherol and $\delta$ tocopherol. 
588

\section{Totalphenolic content}

The total phenolic content (TPC) of oil samples was determined according to the method applied by Singleton and Rossi (1965) using Folin-Ciocalteu's reagent. Distilled water $(3.16 \mathrm{~mL})$ was mixed with a DMSO solution of the test compound $(40 \mu \mathrm{L}$ ), followed by the addition $200 \mu \mathrm{L}$ of FolinCiocalteu's reagent. Then $600 \mu \mathrm{L}$ of $20 \%$ sodium carbonate solution was added and the solutions were mixed again. After, the solutions were placed at room temperature for $2 \mathrm{~h}$. Finally, the absorption of the developed blue color was measured at 765 $\mathrm{nm}$, using a UV-visible spectrophotometer. Results were expressed as $\mathrm{mg}$ gallic acid equivalents (GAE) per $100 \mathrm{~g}$ of oil.

\section{Antioxidant activity}

TEAC method was used to determine antioxidant activity in walnut fruits. The method is based on the ability of antioxidant molecules to quench the long-lived ABTS radical cation (ABTS9+), a blue-green chromophore with characteristic absorption at $734 \mathrm{~nm}$, compared with that of Trolox, a water-soluble vitamin E analog (Pellegrini et al., 2006). The addition of antioxidants to the preformed radical cation reduces it to ABTS, determining a decolorization. A stable stock solution of ABTS was produced by reacting a 7 $\mathrm{mmol} / \mathrm{L}$ aqueous solution of ABTS with $2.45 \mathrm{mmol} / \mathrm{L}$ potassium persulfate (final concentration) and allowing the mixture to stand in the dark at room temperature for $12-16 \mathrm{~h}$ before use (Pellegrini et al., 2006). At the beginning of the analysis day, an ABTS + working solution was obtained by the dilution in ethanol of the stock solution to an A of 0.7010 .02 AU at $734 \mathrm{~nm}$, verified by a Hewlett Packard 8453 diode array spectrophotometer, and used as mobile phase in a flowinjection system, according to Pellegrini $e t$ al. (2006). Results were expressed as TEAC in $\mu \mathrm{mol}$ TE/g FW.

\section{Statistical analysis}

All data were analyzed using SPSS software and procedures. Analysis of variance tables were constructed using the Least Significant Difference (LSD) method at $p<0.01$.

\section{Results and Discussion}

\section{Physico-chemical characteristics}

The results indicated that there were significant differences $(\mathrm{p}<0.05)$ among walnut genotypes sampled from Gumushane province for all fruit physic-chemical characteristics (Table 1). Fruit weight and kernel ratio of walnut genotypes ranged from 7.43 ('G-7') to $12.61 \mathrm{~g}$ ('G-11') and 45.10 ('G-10') to $57.83 \%$ ('G-7'). The standard control cultivar 'Sebin' had $9.03 \mathrm{~g}$ fruit weight and $46.10 \%$ kernel ratio (Table 1). According to these results, 8 genotypes had higher fruit weight than cv. 'Sebin' and 14 genotypes had higher kernel ratio than cv. 'Sebin' (Table 1). Previously, Akca and Koroglu (2005), Akcay and Tosun (2005), Unver (2005) and Dogan et al. (2005) showed genotype dependent fruit weight and kernel ratio in walnuts grown in middle parts of Turkey that ranged from 7.82 to $18.74 \mathrm{~g}$ for fruit weight and 42.88 to $67.14 \%$ for kernel ratio, respectively. All those studies indicate that walnut genotypes grown in different parts of the Anatolia differ among each other in terms of fruit weight. This variability may be due to long term seed propagation, different growing conditions, climate, geography, cultural applications and maturation stage. Fruit weight and kernel ratio are effective parameter not only as an indicator of appearance, for describing external and internal quality of walnut fruits, but also for walnut breeding studies.

The results showed significant differences $(p<0.05)$ among the walnut genotypes in terms of protein, crude oil, total dietary fiber, ash and carbohydrates (Table 1). Oil was the predominant component, followed by carbohydrates and protein (Table 1).

Protein content varied from 11.09 ('G-10') to $18.16 \%$ ('G12 '), crude oil varied from 55.38 ('G-5') to $65.15 \%$ ('G-11'), total dietary fiber varied from 2.90 ('G-13') to $4.12 \%$ ('G-6'), ash content varied from 1.61 ('G-6') to 2.08\% ('G-14') and carbohydrates varied from 12.01 ('G-11') to $17.89 \%$ ('G-5'), respectively (Table 1). Protein, crude oil, total dietary fiber, ash and carbohydrates content of cv. 'Sebin' were 15.05\%, 59.10\%, $3.75 \%, 1.78 \%$ and $14.02 \%$, respectively (Table 1 ). The results indicated that seven genotypes had higher protein content than cv. 'Sebin', ten genotypes had higher crude oil content than cv. 'Sebin' and eleven genotypes had higher total dietary fiber content than cv. 'Sebin', while twelve genotypes among those under study had higher carbohydrates than cv. 'Sebin' (Table 1); all these data highlight the importance of genotypes considered in the experiment. Previously, Simsek (2010) reported average protein, oil and ash content between 13.70$20.18 \%, 58.88-65.64 \%$ and $1.88-2.89 \%$ among walnut selections. Kahraman (2006) reported protein content between $15.61-27.50 \%$ and oil content in walnut genotypes between 51.70-72.80\%, respectively. Sahin and Akbas (2001) reported that 35 walnut genotypes from Turkey contained 13.59-22.99\% protein, $56.38-70.59 \%$ oil and $1.66-2.81 \%$ ash. Pereira et al. (2008) reported protein, total oil and carbohydrate content of walnuts from Portugal ranged from 14.38 to $18.03 \%, 68.83$ to $72.14 \%$ and 3.75 to $6.10 \%$, respectively. Gharibzahedi et al. (2014) reported protein, total oil, carbohydrate, ash and fiber content of 3 walnut cultivars from Iran that ranged from 13.77 to $14.92 \%, 62.3-67.3 \%$, 12.84 to $16.67 \%, 2.09$ to $2.24 \%$ and 4.2 to $4.6 \%$, respectively. The current results are comparable with the above reported studies. The differences could be attributed to the year of harvest and the accompanying environmental conditions. Thus, different values of temperature, rainfall and light can influence the chemical composition of fruits.

\section{Fatty acid content}

Fatty acid profile of walnut genotypes and cv. 'Sebin' are given in Table 2. There were statistical differences among genotypes for linoleic, linolenic, oleic and palmitic acid content $(\mathrm{p}<0.05)$

The major fatty acids in the walnut samples were linoleic (C18:2), followed by oleic (C18:1w9), $\alpha$-linolenic (C18:3) and palmitic acid (C16:0). Linoleic acid was the most abundant fatty acid in all the walnut fruits analyzed, with values ranging from 49.30 ('G-9') and 58.20\% ('G-12'). Linolenic, oleic and palmitic acid content of genotypes were between 13.40 ('G-2') and $15.33 \%$ ('G-9'); 17.30 ('G-12') and 25.15\% ('G-9') and 4.64 ('G-10') and 6.73\% ('G-11'), respectively. The cultivar 'Sebin' had $55.03 \%, 14.17 \%, 19.06 \%$ and $7.81 \%$ of linoleic, linolenic, oleic and palmitic acid content (Table 2). Rabrenovic et al. (2011) revealed that predominant fatty acids in fruits of 5 walnut cultivars ('Sampion', 'Jupiter', 'Sejnovo', 'Elit', and 'Geisenheim 139') grown in Serbia were linoleic (57.2-65.1\%), oleic (15.9-23.7\%), linolenic (9.1-13.6\%) and palmitic acid (6.3-7.7\%). Ozrenk et al. (2011) previously reported linoleic 
Table 1. Fruit physico-chemical characteristics of walnut tested genotypes and 'Sebin' cultivar

\begin{tabular}{cccccccc}
\hline Genotype & $\begin{array}{c}\text { Fruit weight } \\
(\mathrm{g})\end{array}$ & $\begin{array}{c}\text { Kernel ratio } \\
(\%)\end{array}$ & $\begin{array}{c}\text { Protein } \\
(\%)\end{array}$ & $\begin{array}{c}\text { Crude oil } \\
(\%)\end{array}$ & $\begin{array}{c}\text { Total } \\
\text { dietary fiber } \\
(\%)\end{array}$ & $\begin{array}{c}\text { Ash } \\
(\%)\end{array}$ & $\begin{array}{c}\text { Carbohydrates } \\
(\%)\end{array}$ \\
\hline 'G-1' & 7.94 & 51.15 & 16.60 & 56.40 & 3.81 & 1.91 & 17.10 \\
'G-2' & 8.87 & 56.33 & 14.83 & 58.62 & 3.77 & 2.01 & 17.42 \\
'G-3' & 8.51 & 55.07 & 15.40 & 60.72 & 4.07 & 1.87 & 16.64 \\
'G-4' & 12.06 & 48.16 & 16.02 & 58.34 & 3.79 & 1.70 & 16.78 \\
'G-5' & 9.03 & 46.40 & 15.40 & 55.38 & 3.85 & 1.74 & 17.89 \\
'G-6' & 11.15 & 49.27 & 17.06 & 56.21 & 4.12 & 1.61 & 15.49 \\
'G-7' & 7.43 & 57.83 & 15.30 & 60.82 & 3.77 & 1.80 & 14.96 \\
'G-8' & 10.40 & 48.34 & 13.40 & 62.15 & 3.70 & 2.01 & 15.07 \\
'G-9' & 9.56 & 47.96 & 13.45 & 62.28 & 3.68 & 1.67 & 12.14 \\
'G-10' & 11.02 & 45.10 & 11.09 & 64.10 & 3.83 & 1.71 & 15.17 \\
'G-11' & 12.61 & 47.42 & 12.10 & 65.15 & 4.01 & 1.73 & 12.01 \\
'G-12' & 9.17 & 51.10 & 18.16 & 59.62 & 3.70 & 1.95 & 13.22 \\
'G-13' & 10.93 & 55.40 & 14.67 & 60.28 & 2.90 & 1.84 & 15.40 \\
'G-14' & 8.27 & 56.72 & 12.10 & 61.60 & 3.85 & 2.08 & 14.70 \\
'G-15' & 8.64 & 50.05 & 11.96 & 62.05 & 3.77 & 1.95 & 16.81 \\
'Sebin' & 9.03 & 46.10 & 15.05 & 59.10 & 3.75 & 1.78 & 14.02 \\
\hline LSD05 & 2.11 & 6.36 & 4.12 & 8.17 & 0.17 & 0.18 & 2.15 \\
\hline
\end{tabular}

Table 2. Fatty acid content of walnut tested genotypes and 'Sebin' cultivar

\begin{tabular}{ccccc}
\hline Genotype & $\begin{array}{c}\text { Linoleic } \\
(\%)\end{array}$ & $\begin{array}{c}\text { Linolenic } \\
(\%)\end{array}$ & $\begin{array}{c}\text { Oleic } \\
(\%)\end{array}$ & $\begin{array}{c}\text { Palmitic } \\
(\%)\end{array}$ \\
\hline 'G-1' & 55.02 & 13.60 & 22.41 & 6.32 \\
'G-2' & 52.64 & 13.40 & 24.39 & 6.51 \\
'G-3' & 54.40 & 13.69 & 22.07 & 5.91 \\
'G-4' & 54.15 & 13.87 & 20.89 & 6.68 \\
'G-5' & 53.10 & 13.95 & 23.28 & 6.14 \\
'G-6' & 55.06 & 14.07 & 20.74 & 5.98 \\
'G-7' & 54.40 & 15.02 & 19.40 & 6.10 \\
'G-8' & 51.28 & 14.40 & 23.20 & 6.42 \\
'G-9' & 49.30 & 15.33 & 6.30 \\
'G-10' & 53.42 & 14.01 & 25.15 & 4.64 \\
'G-11' & 56.02 & 14.20 & 24.10 & 6.73 \\
'G-12' & 58.20 & 15.15 & 19.60 & 6.42 \\
'G-13' & 53.35 & 17.30 & 6.00 \\
'G-14' & 56.10 & 14.47 & 21.30 & 6.51 \\
'G-15' & 55.78 & 18.08 & 5.98 \\
\hline 'Sebin' & 55.03 & 13.87 & 19.95 & 7.81 \\
\hline LSD05 & 4.11 & 14.17 & 19.06 & 0.30 \\
\hline
\end{tabular}

Table 3. Tocopherol content (mg/100 g oil samples) of walnut tested genotypes and 'Sebin' cultivar

\begin{tabular}{|c|c|c|c|c|}
\hline Genotype & $\alpha$-Tocopherol & $\gamma+\beta$-Tocopherol & $\delta$-Tocopherol & Total tocopherol \\
\hline 'G-1' & 1.9 & 34.2 & 3.2 & 39.3 \\
\hline 'G-2' & 2.6 & 38.5 & 2.1 & 43.2 \\
\hline 'G-3’' & 1.8 & 39.2 & 2.9 & 43.9 \\
\hline 'G-4’' & 2.1 & 36.7 & 3.5 & 42.3 \\
\hline 'G-5’' & 1.7 & 35.8 & 3.6 & 41.1 \\
\hline 'G-6’ & 2.0 & 26.1 & 1.9 & 30.0 \\
\hline 'G-7’ & 1.4 & 30.7 & 2.8 & 34.9 \\
\hline 'G-8’ & 1.3 & 29.3 & 2.0 & 32.6 \\
\hline ‘G-9’' & 1.4 & 39.8 & 3.1 & 44.3 \\
\hline ‘G-10’ & 1.4 & 37.3 & 3.2 & 41.9 \\
\hline 'G-11' & 1.9 & 31.2 & 3.0 & 36.1 \\
\hline 'G-12’ & 1.7 & 30.3 & 3.7 & 35.7 \\
\hline 'G-13' & 1.6 & 40.4 & 2.4 & 44.4 \\
\hline 'G-14' & 2.0 & 29.8 & 2.7 & 34.5 \\
\hline 'G-15' & 1.5 & 33.4 & 3.1 & 38.0 \\
\hline ‘Sebin’ & 1.4 & 33.1 & 2.4 & 36.9 \\
\hline LSD05 & 0.3 & 5.2 & 0.7 & 7.4 \\
\hline
\end{tabular}

acid 40.95-59.98\%, oleic acid 15.90-40.69\%, linolenic acid Celik (2005) determined linoleic acid 41.13-61.15\%, oleic acid 8.92-17.81\% and palmitic acid 4.98-6.77\% in fruits of 32 local $22.39-49.12 \%$, palmitic acid $6.01-10.21 \%$ in fruits of walnut walnut genotypes from Van province in Turkey. Unver and genotypes and cultivars. Muradoglu et al. (2010) also 
590

determined linoleic acid 50.58-66.60\%, oleic acid 14.88$28.71 \%$ and linolenic acid 9.16-16.42\% among walnut selections. The order and proportion of the main fatty acid in the hereby walnut samples were generally similar to the data obtained within the above mentioned studies. In the current study, several walnut genotypes contained higher amounts of linoleic acid, oleic acid, linolenic and palmitic than cv. 'Sebin' (Table 2). Walnut oil composition can be influenced by genotype, geographical location, climatic condition, cultural practices, maturity of the seed at harvest, its position on the plant and its handling after harvest (Crews et al., 2005). The seed propagated genotypes in this study have nutritionally promising levels of fatty acids. Out of these fatty acids, $\alpha$ linolenic acid (C18:3), which has been associated with health benefits, was present in a significant amount especially in the genotype 'G-9' (15.30\%).

\section{Tocopherols}

As indicated in Table 3, there were statistical differences of tocopherols found in walnut fruits of the tested genotypes $(\mathrm{p}<$ 0.05 ). The total content of tocopherols in the analyzed samples ranged between 30.0 and $44.4 \mathrm{mg} / 100 \mathrm{~g}$ oil, which is comparable with other data published Demir and Cetin (1999), Savage et al. (1999), Crews et al. (2005). Rabrenovic et al. (2011) reported total tocopherol in 5 walnut cultivars grown in Serbia was found between 28.4 and $42.4 \mathrm{mg} / 100 \mathrm{~g}$. The highest content of total tocopherols was found in 'G-13' genotype fruit oil extracted by the Soxhlet method, while the lowest content was found in the 'G-6' genotype. The cultivar 'Sebin' had $36.9 \mathrm{mg} / 100 \mathrm{~g}$ total tocopherol in oil (Table 3). The current research verified the dominant presence of $\gamma$ Tocopherol in walnut oil. The content of $\gamma$-Tocopherol ranged between 26.1-40.4 mg/100 g oil. Rabrenovic et al. (2011) reported $\gamma$-Tocopherol in walnut fruits between 25.4 and 38.4 $\mathrm{mg} / 100 \mathrm{~g}$ oil, which shows some similarities with the hereby results. $\beta$-Tocopherol was present in a significantly smaller percentage and was difficult to separate from $\gamma$-Tocopherol. Amaral et al. (2005) studied 9 commercial walnut cultivars in Portugal and reported that $\gamma$-Tocopherol was the major compound in all samples, ranging from 17.2 to $26.2 \mathrm{mg} / 100 \mathrm{~g}$ oil, followed by $\alpha$-Tocopherol and $\delta$-Tocopherols, ranging from 0.9 to $1.7 \mathrm{mg} / 100 \mathrm{~g}$ and from 0.8 to $1.7 \mathrm{mg} / 100 \mathrm{~g}$, respectively. These data should help in selecting genotypes that are suitable for commercial production of walnut oil in Turkey.

\section{Total phenolic content and antioxidant activity}

Total phenolics and antioxidant activity of the analyzed walnut genotypes and cv. 'Sebin' are given in Table 4. There were found statistically significant differences in the level of total phenolic and antioxidant activity among the assayed genotypes $(p<0.05)$ (Table 4$)$.

Total phenolic contents of walnut genotypes ranged from 1,107 ('G-1') to 1,876 ('G-12') mg GAE/100 g. The cultivar 'Sebin' had 1,142 mg GAE/100 g total phenolic that was lower than the majority of studied walnut genotypes (Table 4). It was clear that the genotypes strongly influenced the extent of total phenolic accumulation in walnut fruits in the study. Previously total phenolic content of walnut cultivars from different countries were reported between 1,071-2,370 mg GAE/100 g nut (Anderson et al., 2001; Arranz et al., 2008; Labuckas et al., 2008), which indicates good accordance with the hereby study. Abe $e t$ al. (2010) determined total phenols of nuts including walnut. They found total phenol 50-2,499 $\mathrm{mg} \mathrm{GAE} / 100 \mathrm{~g}$ in descending order walnuts $(2,499)>$ pecans $(703)>$ peanuts (597) $>$ pistachios $(576)>$ cashew nuts (381) > almonds (114) $>$ hazelnuts (111) > Brazil nuts (106) > chestnuts $(92)>$ macadamias (87) > pinhao seeds (50). Wu et al. (2004) reported total phenol contents ranging from 68 to $2,016 \mathrm{mg}$ $\mathrm{GAE} / 100 \mathrm{~g}$ for 10 nut varieties and walnut had the highest value (2,016 mg GAE/100 g). Kornsteiner $e t$ al. (2006) also reported the highest values for walnuts (from 1,020 to 2,052 mg GAE/100 g), followed by pecans (from 1,022 to $1,444 \mathrm{mg}$ $\mathrm{GAE} / 100 \mathrm{~g}$ ) and pistachios (from 492 to $1,442 \mathrm{mg} \mathrm{GAE} / 100$ g).

Walnut phenolic compounds are composed from tannins (Fukuda et al., 2003). Tannins in walnut fruit are responsible for the astringency taste of fruit and color of skins (Deshpande et al., 1986). The total phenols in walnuts are higher than blueberries (531 mg GAE/100 g), plums (367 mg GAE/100 g) and raisins (1,065 mg GAE/100 g) (USDA, 2007). It can be concluded that besides other fruits, walnut might be also a good source of total phenolics. The various factors such as genotype, agronomic practices, maturity level at harvest, postharvest storage, climatic and geographical locations affect the total phenolic content of horticultural plants (Veberic et al., 2009).

Total antioxidant activity of the 15 walnut genotypes and cv. 'Sebin' fruit extracts determined by TEAC method is shown in Table 4. The antioxidant capacity was statistically highly different $(\mathrm{p}<0.05)$ among walnut genotypes in TEAC antioxidant-determining method (Table 4).

The genotype 'G-12' showed the higher total antioxidant capacity in TEAC as $158 \mu \mathrm{m}$ of TE per g. The lowest antioxidant capacity was seen in 'G-1' with $98 \mu \mathrm{m}$ of TE per $\mathrm{g}$. The cultivar 'Sebin' had the antioxidant capacity $104 \mu \mathrm{m}$ of TE per $\mathrm{g}$, indicating a lower value than the majority of walnut genotypes (Table 4). Previously TEAC value of walnuts was found $137 \mu \mathrm{mol}$ TE per g FW (Pellegrini et al., 2006), which in accordance with the hereby results. Abe et al. (2010) showed that walnut fruit are exceptional rich for antioxidants and they reported an intense antioxidant activity (TEAC method) average $120 \mu \mathrm{mol}$ Trolox eq/g, followed by pecan $(58 \mu \mathrm{mol}$ Trolox eq/g), chestnuts $(6 \mu \mathrm{mol}$ Trolox eq/g), pistachio $(4$ $\mu \mathrm{mol}$ Trolox eq/g) and hazelnut ( $4 \mu \mathrm{mol}$ Trolox eq/g).

Table 4. Total phenolics and antioxidant activity of walnut tested genotypes and 'Sebin' cultivar

\begin{tabular}{ccc}
\hline Genotype & $\begin{array}{c}\text { Total phenolic } \\
(\text { mg GAE/100 g) }\end{array}$ & $\begin{array}{c}\text { TEAC } \\
(\mu \text { mol Trolox equivalent/g) }\end{array}$ \\
\hline 'G-1' & 1,107 & 98 \\
'G-2' & 1,420 & 101 \\
'G-3' & 1,640 & 112 \\
'G-4' & 1,318 & 105 \\
'G-5' & 1,432 & 109 \\
'G-6' & 1,400 & 98 \\
'G-7' & 1,215 & 93 \\
'G-8' & 1,340 & 105 \\
'G-9' & 1,703 & 140 \\
'G-10' & 1,715 & 147 \\
'G-11' & 1,545 & 111 \\
'G-12' & 1,876 & 158 \\
'G-13' & 1,760 & 135 \\
'G-14' & 1,528 & 119 \\
'G-15' & 1,644 & 128 \\
'Sebin' & 1,142 & 104 \\
\hline LSD05 & 141 & 0.21 \\
\hline
\end{tabular}


The TEAC method (trolox equivalent antioxidant capacity) is one of the most used techniques for quantifying radicals, which can be scavenged by some antioxidant. It is based on scavenging of the cation radical originated by the oneelectron oxidation of the synthetic chromophore 2,2'-azinobis (3- ethylbenzothiazoline-6-sulfonate (ABTS•) to $\mathrm{ABTS}^{++}$ (Artes et al., 1993). In the current study, a big diversity among the tested genotypes and well-known cultivar was found in terms of antioxidant capacity. It is known that genetics, harvest season, origin, environmental conditions, soil composition, maturity level and the methods of cultivation highly influence the composition of nuts (Pellegrini et al., 2006).

\section{Conclusions}

A large variation in physico-chemical, fatty acids, tocopherols, total phenols and antioxidant activity was found evaluating the walnut genotypes in the present study. Most of the local genotypes had higher content of those substances compared with cv. 'Sebin' indicating their importance and thus they can be considered promising as a valuable functional food for fresh consumption and for walnut processors. Also, elite genotypes can be selected for further evaluations in the framework of breeding and final, new cultivar release programs can be established. In addition, the selections with relatively higher total phenols, antioxidant activity and tocopherols may offer significant marketing advantage, due to consumer preference for antioxidant rich products. The data reported in the current paper confirmed that walnuts are a rich source of important nutrients that can be beneficial to human health as well.

\section{References}

Abe LT, Lajolo FM, Genovese MI (2010). Comparison of phenol content and antioxidant capacity of nuts. Ciência e Tecnologia de Alimentos 30(1):254-259.

Akca Y, Koroglu E (2005). Study on selection of superior walnut types in Iskilip walnut populations. Bahce Ceviz 34(1):41-48.

Akcay ME, Tosun I (2005). Walnut selection in III. sub-region (Gemlik, Orhangazi, Iznik and Mudanya ) of Bursa province. Bahce Ceviz 34(1):57-62.

Amaral JS, Casal S, Pereira JA, Seabra RM, Oliveira BPP (2003). Determination of sterol and fatty acid compositions, oxidative stability, and nutritional value of six walnut (Juglans regia $\mathrm{L}$.) cultivars grown in Portugal.Journal of Agricultural and Food Chemistry 51:7698-7702.

Anderson KJ, Teuber SS, Gobeille A, Cremin P, Waterhouse AL, Steinberg FM (2001). Walnut polyphenolics inhibit in vitro human plasma and LDL oxidation. Journal of Nutrition 131:2837-2842.

Arranz S, Jimenez JP, Saura-Calixto F (2008). Antioxidant capacity of walnut (Juglans regia $\mathrm{L}$.): Contribution of oil and defatted matter. European Food Research and Technology 227:425-431.

AOAC (1995). Official methods of analysis (16th Edn). AOAC International, Arlington, VA, pp 16-17.

Artes F, Escriche AJ, Martinez JA, Marin JG (1993). Quality factors in four varieties of melon (Cucumis melo L.). Journal of Food Quality 16:91100.
Beyhan OE, Kaya I, Șen SM, Doğan M (1995). Fatty acid composition of walnut types selected in Darende. Turkish Journal of Agricultural and Forestry 19(4):299-302.

Çaglarirmak N (2003). Biochemical and physical properties of some walnut genotypes (Juglans regia L.). Nahrung/ Food 47(1):28-32.

Chen C-YO, Blumberg JB (2008). Phytochemical composition of nuts. Asian Pacific Journal of Clinical Nutrition 17:329-332.

Crews C, Hough P, Godward J, Brereton P, Lees M, Guiet S, Winkelmann W (2005).Study of the main constituents of some authentic walnut oils. Journal of Agricultural and Food Chemistry 53(12):4853-4860.

Demir C, Cetin M (1999). Determination of tocopherols, fatty acids and oxidative stability of pecan, walnut and sunflower oils. Deutsche Lebensmittel-Rundschau 95:278-282.

Deshpande SS, Cheryan M, Salunkhe DK (1986). Tannin analysis of food products. CRC Critical Review in Food Science and Nutrition 24(4):401-449.

Dogan A, Kazankaya A, Gun A, Askin MA, OguzHI, Celik F (2005). Fruit characteristics of some Turkish walnut genotypes and cultivars (Juglan regia L.). Asian Journal of PlantSciences 4:486-488.

Ercisli S (2004). A short review of the fruit germplasm resources of Turkey. Genetic Resources and Crop Evolution 51:419-435.

Ercisli S, Sayinci B, Kara M, Yildiz C, Ozturk I (2012). Determination of size and shape features of walnut (Juglans regia $\mathrm{L}$.) cultivars using image processing. Scientia Horticulturae 131:47-55.

FAO (2012).FAOSTAT Production Crops. Retrieved 2016June 12 from http://faostat.fao.org/site/567/defaultaspx\#ancor.

Fukuda T, Ito H, Yoshida T (2003). Antioxidative polyphenols from walnuts (Juglans regia L.). Phytochemistry 63:795-801.

Gharibzahedi SMT, Mousavi SM, Hamedi M, Khodaiyan F (2014). Determination and characterization of kernel biochemical composition and functional compounds of Persian walnut oil. Journal of Food Science and Technology 51(1):34-42.

Greve C, Mc Granahan G, HaseyJ,Synder R, Kelly K, Gold HD, Labavitch $\mathrm{J}$ (1992). Variation in polyunsaturated fatty acids composition of Persian walnut.Journal of American Social Heart Science 117(3):518-522.

Grosso NR, Nepote V, Guzman CA (2000). Chemical composition of some wild peanut species (Arachis L.) seeds. Journal of Agricultural and Food Chemistry 48(3):806-809.

Kahraman KA (2006). The selection of walnuts in Aksaray province. MS Thesis. Selcuk University.

Kornsteiner M, Wagner K, Elmadfa I (2006). Tocopherols and total phenolics in 10 different nut types. Food Chemistry 98(2):381-387.

Labuckas DO, Maestri DM, Perelló M, Martínez ML, Lamarque AL (2008). Phenolics from walnut (Juglans regia L.) kernels: Antioxidant activity and interactions with proteins. Food Chemistry 10:607-612.

Maguire LS, O'Sullivan M, Galvin K, O'Connor TP, O'Brien NM (2004). Fatty acid profile, tocopherol, squalene and phytosterol content of walnuts, peanuts, hazelnuts and the macadamia nut. International Journal of Food Science and Nutrition 55:171-178.

Miraliakbari H, Shahidi F (2008). Antioxidant activity of minor components of tree nut oils. Food Chemistry 111:421-427.

Muradoglu F, Oguz HI, Yildiz K, Yilmaz H (2010). Some chemical composition of walnut (Juglans regia L.) selections from Eastern 
Turkey. African Journal of Agricultural Research 5(17):2379-2385.

Ozrenk K, Kaya T, Balta F, Kan T (2011). Comparison of some pomological and chemical characteristics of walnuts grown in lake Van basin. Journal of the Institute of Science and Technology 1(4):15-22.

Paquat C, Houtfenne A (1987). IUPAC, standard methods for the analysis of oils, fats and derivatives, 7th Ed. Oxford, Blackwell Scientific Publications.

Pellegrini N, Serafini M, Salvatore S, Del Rio D, Bianchi M, Brighenti F (2006). Total antioxidant capacity of spices, dried fruits, nuts, pulses, cereals and sweets consumed in Italy assessed by three different in vitro assays. Molecular Nutrition and Food Research 50:1030-1038.

Pereira JA, Oliveira I, Sousa A, Ferreira ICFR, Bento A, Estevinho L (2008). Bioactive properties and chemical composition of six walnut (Juglans regia L.) cultivars. Food and Chemical Toxicology 46:2103-2111.

Pocklington WD, Dieffenbacher A (1988). Determination of tocopherols and tocotrienols in vegetable oils and fats by high performance liquid chromatography. Pure and Applied Chemistry 60:877-892.

Rabrenovic B, Dimic E, Maksimovic M, Sobajic S, Gajic-Krstajic L (2011). Determination of fatty acid and tocopherol compositions and the oxidative stability of walnut (Juglans regia l.) cultivars grown in Serbia. Czech Journal of Food Sciences 29(1):7478.

Sabate J, Fraser GE, Burke K, Knutsen SF, Benett H, Linstead KD (1993). Effects of walnuts on serum lipid levels and blood pressure in normal men. TheNewEngland Journal of Medicine 328 (9):603-607.

Sahin I, Akbas H (2001). Researches on the technological properties of walnuts gathered from different types and areas (in Turkish). Proceedings of First National Walnut Symposium of Turkey pp 104 114.

Savage GP (2001). Chemical composition of walnuts (Juglans regia L.) grown in New Zealand. Plant Foods for Human Nutrition 56(1):7582.
Sen SM, Tekintas E (1992). A study on the selection of Adilcevaz walnuts. ActaHorticulturae 317:171-174.

Singleton VL, Rossi JL (1965). Colorimetry of total phenolics with phosphomolybdic-phosphotungstic acid reagents. American Journal Enology and Viticulture 16:144158.

Simsek M (2010). Selection of walnut types with high fruit bearing and quality in Sanliurfa population. International Journal of Physical Sciences 5(7):992-996.

Unver H (2005). Studies on varietal selection in walnut (Juglans regia L.) populations of Ankara province. MS Thesis. Ankara University, GraduateSchool of Natural and Applied Sciences.

Unver H, Celik M (2005). Breeding of walnuts (Juglans regia L.) from Ankara provinceviaselection. Bahce 34(1):83-89.

USDA (2007). Oxygen Radical Absorbance Capacity (ORAC) of Selected Foods. Retrieved 2016 May 14 from http://www.ars.usda.gov/SP2UserFiles/-Place/12354500.

Veberic R, Jakopic J, Stampar F, Shmitzer V (2009). European elderberry (Sambucus nigra L.) rich in sugars, organic acids, anthocyanins and selected polyphenols. Food Chemistry 114(2):511-515.

Wu X, Beecher GR, Holden JM, Haylowitz DB, Gebhardt SE, Prior RL (2004). Lipophilic and hydrophilic antioxidant capacities of common foods in the United States. Journal of Agricultural and Food Chemistry 52(12):4026-4037.

YangJ, Liu RH, Halim L (2009). Antioxidant and antiproliferative activities of common edible nut seeds. LWT-Food Science and Technology 42:1-8.

Zwarts L, Savage GP, McNeil BL (1999). Fatty acid content of New Zealand-grown walnuts (Juglans regia L.). International Journal of Food Scienceand Nutrition 50(3):189-194. 